\title{
Burden Research Medal and Prize (1969-1989)
}

\author{
Yvonne V. Wiley, Consultant Psychiatrist and Senior Lecturer in Mental Handicap, \\ University of Bristol, Stoke Park Hospital, Stapleton, Bristol BS16 1QU
}

At the meeting on 10 June 1969, the Burden Trust instituted an annual award, 'The Burden Research Medal and Prize', as a contribution to the Diamond Jubilee of the foundation of Stoke Park Hospital on 1 April 1909, by the Reverend H. N. Burden and to encourage future research in the field of mental handicap. The Award consists of a gold medal and a prize of $£ 500$.

The Burden Research Medal and Prize is now being awarded biennially for outstanding research work which has been either published, accepted for publication, or presented as a paper to a learned society, during the preceding three calendar years. The Award is open to all registered medical practitioners, the greater part of whose time is spent working in the field of mental handicap or in a closely related specialty in the United Kingdom or the Republic of Ireland.

The Awards Committee of the Burden Research Medal and Prize consists of the following members:

(a) a member of the Burden Trust who is Chairman of the Awards Committee

(b) the Senior Consultant Psychiatrist at Stoke Park Hospital, who acts as the Secretary of the Awards Committee

(c) a representative of the Royal College of Psychiatrists who is the Chairman of the Section for the Psychiatry of Mental Handicap, or a suitable person nominated by him or her

(d) a representative of the University of Bristol

(e) a nominee of the Medical Research Council.

\section{Winners of the Burden Research Medal} and Prize to-date

1970 Dr B. W. Richards, St Lawrence's Hospital, Caterham, Surrey

1971 Dr J. Jancar, Stoke Park Hospital, Stapleton, Bristol

1972 Dr G. McCoull, OBE, Prudhoe Hospital, Prudhoe, Northumberland

1973 Dr P. Sylvester, St Lawrence's Hospital, Caterham, Surrey

1974 Dr V. A. Cowie, Queen Mary's Hospital for Children, Carshalton, Surrey

1975 Dr D. A. Primrose, The Royal Scottish National Hospital, Larbert, Stirlingshire, Scotland

1978 Dr W. A. Heaton-Ward, Stoke Park Hospital, Stapleton, Bristol

1980 Dr A. H. Reid, Strathmartine Hospital, Dundee, Scotland

1982 Dr J. A. Corbett, Hilda Lewis House, Bethlem Royal Hospital, London

1984 Not awarded

1986 Dr K. A. Day, Northgate Hospital, Morpeth, Northumberland

1988 Dr W. I. Fraser, Gogarburn Hospital, Edinburgh, Scotland

It is pleasing to note that the last winner has now been appointed to the Chair of Mental Handicap in the University of Wales.

The Burden Research Medal and Prize is presented by the Chairman of the Burden Trust at Stoke Park Hospital.

Professor Fraser was presented with the prize at the Seminar of the Avon Senior Psychiatrists on 8 November this year, where he also delivered a paper entitled 'The Application of Recent Advances in Linguistics to the Mentally Handicapped'. 